officer, Nigeria), deputy director of agriculture, Eastern Region, Nigeria; E. H. Probyn (senior assistant conservator of forests, Cyprus), conservator of forests, Tanganyika; P. E. Glover (research officer (botanist), East African Trypanosomiasis and Tsetse Research and Reclamation Organization), chief field geologist, Kenya; T. H. P. Hartley and J. A. Howarth (agricultural survey officers, Gold Coast), principal agricultural survey officers, Gold Coast; F. A. Leeds and D. Westwood (agricultural officers, Gold Coast), senior agricultural officers, Gold Coast ; L. Lotringer, J. A. Makinde, S. Z. Moczarski and G. E. Okiy (agricultural superintendents, Nigeria), agricultural officers, Nigeria; K. V. W. Nicholls (meteorologist, East Africa High Commission), senior meteorologist, British Caribbean Meteorological Service, Trinidad ; H. T. Shewan (agricultural survey officer, Gold Coast), principal agricultural survey officer, Gold Coast; B. D. A. Beck, plant breeder, Nigeria; S. R. Chant, plant pathologist, Nigeria; C. M. Grieve, agricultural officer, British Honduras; A. D. H. Joblin, agricultural officer, Uganda; R. G. Poultney, pasture research officer, Kenya; J. H. Proctor, entomologist, British Guiana; R. MacDonald, geolcgist, Uganda; R. H. Cammack, scientific officer (mycologist), Nigeria; A. G. Smyth, soil scientist, Nigeria; R. F. Coughlan, veterinary research officer, Federation of Malaya; C. J. Price, veterinary officer, Uganda; J. G. Tremlett, veterinary officer, Northern Rhodesia ; E. M. MeWatt, veterinary officer, British Guiana; T. R. Paton, scientific officer (soil chemist), North Borneo; J. D. Randall, statistician, East Africa High Commission; W. W. Reece, stock development officer, North Borneo; R. A. Eyre-Smith, livestock improvement officer, Kenya; R. L. Sykes, leather chemist, East Africa High Commission; Miss M. S. Timpson, computer, Uganda; R. J. Wedderburn, assistant conservator of forests, Nigeria.

\section{The Night Sky in February}

NEw moon occurs on Feb. 14d. 01h. 10m. U.T., and full moon on Feb. 28d. 18h. 59m. The following conjunctions with the moon take place: Feb. 5d. 18h., Saturn $8^{\circ}$ N.; Feb. 16d. 23h., Mars $5^{\circ}$ S.; Feb. 17d. 09h., Venus $2^{\circ}$ S. ; Feb. 19d. 14h., Jupiter $6^{\circ} \mathrm{S}$. Mercury, in superior conjunction on February 2 , is not well placed for observation until later in the month. On February 14 and 28 it sets at 18h. and 19h. $15 \mathrm{~m}$., respectively, and can be seen in the western sky after sunset in the latter part of the month. Venus is an evening star and sets at $21 \mathrm{~h}$. $05 \mathrm{~m} ., 21 \mathrm{~h} .35 \mathrm{~m}$. and $21 \mathrm{~h} .50 \mathrm{~m}$. on February 1,14 and 28. respectively. The visible portion of the illuminated disk varies between 0.51 and $0 \cdot 34$, and the stellar magnitude is about $-4 \cdot 2$. Mars is visible in the early evening hours, its time of setting being about $20 \mathrm{~h}$. $50 \mathrm{~m}$. during the month. Its stellar magnitude is 1.3 ; in the early part of the month it lies a little south of $\lambda$ Piscium, and towards the end of the month a little south of $\varepsilon$ Piscium. Jupiter sets at $1 \mathrm{~h}$. $15 \mathrm{~m}$., $0 \mathrm{~h} .25 \mathrm{~m}$. and $23 \mathrm{~h}$. $45 \mathrm{~m}$. on February 1, 14 and 28, respectively, its stellar magnitude varying between -2 and $-1 \cdot 8$. At the end of the month the planet lies a little south of $\delta$ Arietis. Saturn rises at $23 \mathrm{~h} .40 \mathrm{~m} ., 22 \mathrm{~h} .45 \mathrm{~m}$. and $21 \mathrm{~h} .55 \mathrm{~m}$. at the beginning, middle and end of the month, respectively. Its stellar magnitude is $0 \cdot 3$, and it lies a little north-east of $\alpha$ Virginis during the whole of February. Occultations of stars brighter than magnitude 6 are as follows, observations being made at
Greenwich: Feb. 2d. Ih. 37.6m., p Leon. $(R)$; Feb. 4 d. 2 h. $58 \cdot 2 \mathrm{~m}$., $q$ Virg. $(R)$. $R$ refers to reappearance. A partial eclipse of the sun, invisible at Greenwich, takes place during Feb. 13-14. It begins on Feb. 13d. $23 \mathrm{~h} .12 \mathrm{~m}$. at lat. $21^{\circ} 55^{\prime}$, long. $-111^{\circ}$, and ends on Feb. 14d. 02h. $45.6 \mathrm{~m}$. at lat. $68^{\circ} 27^{\prime}$, long. $164^{\circ} 08^{\prime}$. The magnitude of the greatest eclipse is 0.760 (sun's diameter $1 \cdot 0$ ).

\section{Announcements}

THE Third General Assembly and International Congress of the International Union of Crystallography will be held in Paris during July 21-28, 1954. These dates have been chosen in consultation with the French National Committee for Crystallography and with the national committees of all the adhering bodies. Further particulars of the meeting will be given from time to time in Acta Crystallographica and elsewhere, or may be obtained from the general secretary of the Union, Dr. R. C. Evans, Crystallographic Laboratory, Cavendish Laboratory, Cambridge.

THE spring conference of the Geographical Association will be held in the Diocesan Training College, Lincoln, during April 7-11, under the presidency of Dr. O. J. R. Howarth. The programme mainly consists of excursions of various sorts, but, in addition to the usual social functions, there will be a number of lectures, including the presidential address for 1952 by Prof. F. Debenham, and also an exhibition of maps, plans, books, etc. Application forms, which must be returned by February 16, and further information can be obtained from the honorary conference secretary, Miss Margaret Goodrich, Training College, Lincoln.

A syMposrum on molecular structure and spectroscopy, on the lines of those of previous years, will be held in the Department of Physics and Astronomy, Ohio State University, during June 15-19. The interpretation of molecular spectroscopic data as well as methods for obtaining such data will be discussed, and, in addition, there will be sessions devoted to aspects of spectroscopy which are of current interest. Further details can be obtained from Prof. Robert A. Oetjen, Department of Physics and Astronomy, Ohio State University, Columbus 10, Ohio.

LIST No. 7 (pp. 77, December 1951) of "Scientific Papers published in the Middle East", now issued by the Middle East Science Co-operation Office, Cairo, includes the papers received by that Office during November 1, 1950-September 30, 1951, and covers Afghanistan, Cyprus, Egypt, Iran, Iraq, Israel, Lebanon, Pakistan, Sudan, Syria and Turkey. There is the usual list of periodicals, arranged by country ; the papers themselves are arranged by sciences and technologies according to the decimal classification.

The Ministry of Agriculture and Fisheries is offering the following scholarships for rural workers, or the children of rural workers, of seventeen years of age or more : ten senior scholarships, tenable at universities or colleges, for degree or diploma courses in an agricultural subject or veterinary science; sixty junior scholarships and six extensions for existing holders, tenable at farm institutes, for oneyear courses. Selection is by interview only. Further information and forms of application (to be completed by March 31) can be obtained from the Secretary (Room 314), 1 Cambridge Terrace, Regent's Park, London, N.W.1, or from the education offices of County Councils. 